American Journal of Applied Sciences 4 (7): 491-495, 2007

ISSN 1546-9239

(C) 2007 Science Publications

\title{
Petrology and Origin of Ultramfic Xenoliths from North Eastern Jordan Volcanoes
}

\author{
Hassan Al-Fugha and Mazen AL-Amaireh \\ Tafila Technical University, Faculty of Engineering, Department of Natural Resources \\ and Chemical Engineering, P.O. Box. 179, Tafila 66110, Jordan
}

\begin{abstract}
The distribution of major, minor and trace elements in the Cenozoic alkali basalt from north-eastern Jordan indicates a homogeneous lava flow from a mantle source. These basaltic rocks contain abundant upper mantle xenoliths (spinal lherzolite, harzburgile and olivine- websterite). Theses xenoliths contain olivine, orthopyroxne, clinoporoxene and a few amounts of spinal. Their mineral assemblages, chemistry, texture and major elements abundances indicate they were derived and equilibrated under upper mantle conditions within temperature range for $970-1090^{\circ} \mathrm{C}$. Pressure estimates based on the spinal lherzolite stability field restrict the xenoliths source depth to around 65 $\mathrm{km}$. The concentrations of incompatible trace elements ( $\mathrm{Ba}, \mathrm{Rb}$ and $\mathrm{Sr}$.) imply a derivation from ultramafic predictive source from the upper mantle with low degree of melting $(<20 \%)$. Low concentration of Lithium and Rubidium in the basalt is used as an argument against the contamination of the basaltic magma during its journey to the surface.
\end{abstract}

Keywords: Alkali olivine basalt, contamination of the basaltic magma, ultramfic xenoliths

\section{INTRODUCTION}

The Tertiary-Quaternary basaltic plateau of northeast Jordan is part of the large intra-continental volcanic province of Harrat Al-Shaam, which covers an area of about $45.000 \mathrm{~km}^{2}$ and extends continuously in a NWSE trend from the southern rim of Damascus basin in Syria across Jordan into the north western parts of Saudi Arabia. In Jordan the volcanic province covers an area of $11414 \mathrm{~km}^{2}$, which occur along the Jordanian rift, mountains in central Jordan and in north eastern Jordan $^{[1]}$. The Cenozoic volcanism in north-eastern Jordan has a relatively long period of magmatic sequence extending from the Oligocene to Holocene ${ }^{[2,3]}$. The extensive volcanism in Jordan was extruded intermittently with the Jordan-Dead Sea Rift and other faulting episodes.

The volcanoes contain abundant upper mantle nodules with composition of harzburgite, olivine westernize and spinal lherzolite.Mantle xenoliths are found in both pyroclastic material and Cenozoic basalt of Jordan, are analogous to worldwide occurrences ${ }^{[4-6]}$. In Jordan different varieties of xenoliths are reported by El-Sharkawi $^{[7]}$, Nasir and Al-Fugha ${ }^{[8]}$ and Al-Fugha ${ }^{[9]}$. The xenoliths are fragments of the lithosphere mantle beneath Jordan, such xenoliths constrain the P-T conditions of melting which prevailed during the generation of the magma which poured during Cenozoic times and led to the formation of alkali basalts in NE Jordan. Mantle xenoliths provide clues of the lithosphere mantle beneath particular regions at the time of their eruption and hence are crucial direct evidence for the nature of the mantle regions where no samples have exposed by tectonic activity ${ }^{[10]}$.

The purpose of this study WAS to describe the occurrence of xenoliths in the basalt of NE volcanoes and to study their mineralogy, chemistry and origin and to make some inferences about the lithosphere mantle underneath that area in Jordan.

Geological setting: The volcanoes of northwestern Jordan are composite volcanoes, built partly of flows and partly of fragmental eject. They rise above the surface of the basaltic flow by $100-120 \mathrm{~m}$. They are composed of fine grained ash, percolates (angular and spherical) and basaltic bombs in different sizes ranging in diameter between 0.5 and $2 \mathrm{~m}$. Exposed at the surface Basaltic layers of blocky lava with an average thickness of $50 \mathrm{~cm}$ are also present. Variety of ultramafic xenoliths occurs mostly within the pyroclastic component of the rock.

Corresponding Author: Mazen AL-Amaireh, Tafila Technical University, Faculty of Engineering, Department of Natural Resources and Chemical Engineering, P.O. Box. 179, Tafila 66110, Jordan 
The xenoliths are mainly lherzolie with a few percent harzburgite and olivine websterite are enclosed within the pyroclastic and basalt with diameters reaching up to $12 \mathrm{~cm}$. Bender ${ }^{[2]}$ subdivided basalt of northwestern Jordan into seven different flows, three of which are exposed, where as the others are only recorded from boreholes. The basalt of northeast Jordan are exposed in several larger and many smaller volcanic necks, flows and pyroclastic deposits, all these volcanic rocks consist of alkali basalt ${ }^{[2]}$. Jordan is part of the Arabian plate, which is drifting to the northeast towards the Tauros-zagros compress ional zone: uplift and tensional depression parallel the Red Sea are developed and the most important one is the NE-SE striking Azraq-Sirhan graben structure. The volcanoes are aligned NNW-SSE and are situated on the east side of a major fault trending NNW-SSE ${ }^{[2]}$.

Petrology mineralogy: The principal mineralogical components of the studied basalts are plagioclase, augite, olivine, apatite and opaque minerals. The average modal composition is 54 vol.\% plagioclase, 25 vol. $\%$ augite, 15 vol.\% olivine and 6 vol. $\%$ accessory minerals. The chemical analyses of investigated basalt rocks are listed in Table 1; they can be classified as alkali olivine basalt.

The northeast basalt and pyroclastic material enclosed xenoliths occur as small and large nodules their colors ranges from grey, olive green, yellow green to dark green in hand specimens. They are usually rounded. They range from 2 to $10 \mathrm{~cm}$ in diameter, coarse-grained olivine and orthpyroxene associated with smaller clinopyroxene and spinal grains are their characteristic features. The xenoliths show reaction rims developed towards their outer boundaries in the enclosing basalts. The ultramafic xenoliths are divided into three groups based on their mineralogy, lherzolite, harzburgite and olivine webstrite, (Fig. 1). The average modal composition of lherzolite, harzburgite and olivine websterite are respectively $74.2,85.6,32.4$ vol.\% olivine, 13.2, 9.5, 21.5 vol.\% orthopyroxene, 9.1, $2.9,41.0$ vol.\% clinpyroxene, $3.4,2.0,3.8$ vol.\% spinal.

The most common texture of xenoliths is protogranular in terms of the nomenclature of Mercier and Nicolas ${ }^{[11]}$. Olivine forms anhedral crystals enclosed in orthopyroxene but also occur as ethereal crystals enclosed in or interbrain with chromdiopside, institute occur as ethereal to subhedral grains, chromadiopside has duller color and common euhedral to subhedral grains are intergrown with spinal. Small euhedral to subhedral spinals are enclosed in olivine and enstatite.

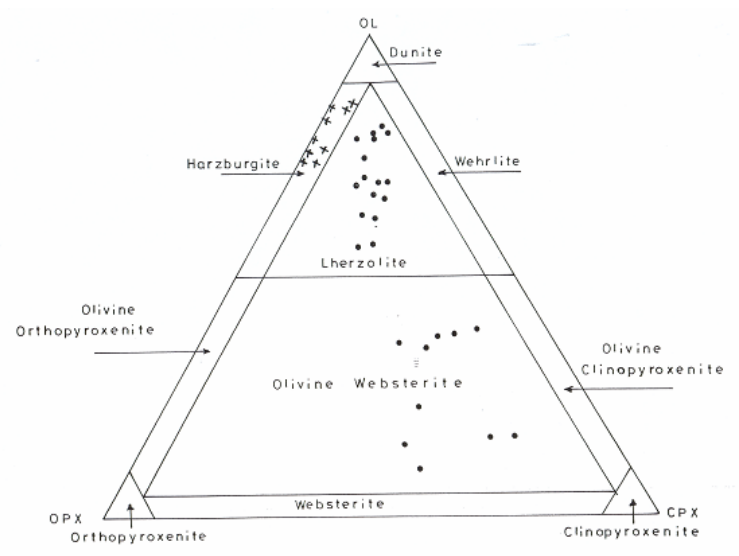

Fig. 1: Plot of modal olivine - orthopyroxene and clinopyoxene of xenoliths from north eastern Jordan volcanoes

Thirty xenoliths representing all principal rock types and many of the minor rock types have been analyzed for major and miner elements composition by microprobe analysis. Tables 2-5 show that composition of olivine, enstatite, chrom-diposide and spinal. Olivine is the main constituent phase in ultramafic xenoliths, the composition of the analyzed olivine (Table 2) is comparable to that in ultramafic xenoliths in alkali basalt suite magmas from world-wide occurrence ${ }^{[4,12,13]}$. The first-rate proportion unselected olivine crystal ranges from 88.25 to $91.0 \%$., typicaly olivine is homogeneous from analyzed rim to core. The enstatite component is the essential constituent of the analyzed orthopyroxene grains.

Table 3 Shows the average composition is $1.3 \%$ Wo, $85.4 \%$ En $13.6 \%$ Fs. The $\mathrm{Fe} / \mathrm{Mg}$ in enstatite correlates well to those of olivine reflecting equilibrium between both coexisting mineral phases. The analyzed enstatite are homogeneous interim of $\mathrm{Ca}, \mathrm{Mg}$ and $\mathrm{Fe}$, but display little increase of $\mathrm{Al}$ and as light decrease of $\mathrm{Cr}$ from core to rim. The $\mathrm{Al}_{2} \mathrm{O}_{3}$ content of enstatite displays relatively a regular increase with increase of the coexisting spinal. The majority of the analyzed clinopyroxene are listed in Table 4; they can be described as chromdiposide in both xenoliths occurrences. The average composition consists of about $45 \% \mathrm{Wo}, 51 \%$ En and $4 \% \mathrm{Fs}$. The Xmg value is correlated with that of enstatite and that of olivine. Individual analyses both of different grains show some zonation in term of $\mathrm{Cr}$ and $\mathrm{Al}$ which decrease from core to rim. The average composition of spinal in (Table 5) is close to $\mathrm{Mg} 0.79, \mathrm{Fe} 0.24$ and $\mathrm{CR} 0.32$. The Xmg value varies from $0.75-0.80$ and the $\mathrm{XCr}$ value from $0.15-0.18$. $\mathrm{Al}$ and $\mathrm{Cr}$ are relatively reversed correlated to each other. 
Am. J. Applied Sci., 4 (7): 491-495, 2007

Table 1: Characteristics of northeastern Jordan basalt

A- Chemical Analysis

\begin{tabular}{|c|c|c|c|c|c|c|c|c|c|}
\hline Wt.\% & NE1 & NE2 & NE3 & NE4 & NE5 & NE6 & NE7 & NE8 & NE9 \\
\hline$\overline{\mathrm{SiO} 2}$ & 47.51 & 46.52 & 46.42 & 47.49 & 48.17 & 49.21 & 48.81 & 46.83 & 47.95 \\
\hline Ti02 & 1.66 & 1.67 & 2.89 & 1.71 & 1.40 & 1.48 & 1.43 & 1.87 & 1.98 \\
\hline AI203 & 14.58 & 13.36 & 13.73 & 14.92 & 15.27 & 15.36 & 14.87 & 15.45 & 15.93 \\
\hline F e203 & 3.16 & 3.17 & 4.39 & 3.71 & 2.90 & 2.98 & 2.93 & 3.37 & 3.48 \\
\hline $\mathrm{FeO}$ & 9.12 & 8.82 & 8.41 & 8.09 & 9.01 & 9.05 & 8.54 & 8.79 & 7.67 \\
\hline $\mathrm{MnO}$ & 0.21 & 0.19 & 0.21 & 0.25 & 0.20 & 0.19 & 0.26 & 0.22 & 0.20 \\
\hline $\mathrm{MgO}$ & 8.75 & 8.35 & 7.92 & 6.95 & 7.16 & 6.96 & 6.08 & 6.95 & 6.24 \\
\hline $\mathrm{CaO}$ & 9.49 & 11.85 & 9.86 & 12.24 & 10.10 & 9.89 & 12.47 & 11.63 & 11.47 \\
\hline $\mathrm{Na} 20$ & 3.46 & 3.02 & 3.36 & 2.80 & 2.93 & 2.91 & 2.52 & 2.21 & 2.74 \\
\hline K20 & 0.80 & 0.75 & 1.43 & 0.63 & 0.65 & 0.65 & 0.64 & 0.68 & 0.87 \\
\hline P203 & 0.38 & 0.51 & 0.28 & 0.23 & 0.53 & 0.20 & 0.23 & 0.22 & 0.30 \\
\hline $\mathrm{H} 2 \mathrm{O}$ & 1.24 & 0.99 & 0.72 & 0.90 & 1.08 & 1.01 & 0.84 & 0.97 & 0.90 \\
\hline Total & 100.36 & 99.20 & 99.62 & 99.92 & 99.40 & 99.89 & 99.62 & 99.19 & 99.73 \\
\hline $\mathrm{Mg} / \mathrm{Mg}+\mathrm{Fe} 2+$ & 0.49 & 0.49 & 0.49 & 0.45 & 0.44 & 0.44 & 0.42 & 0.44 & 0.45 \\
\hline
\end{tabular}

\begin{tabular}{|c|c|c|c|c|c|c|c|c|c|}
\hline $\mathrm{Or}$ & 4.71 & 4.47 & 8.48 & 3.74 & 3.86 & 3.85 & 3.80 & 4.05 & 5.15 \\
\hline$\overline{\mathrm{Ab}}$ & 25.49 & 18.63 & 21.08 & 22.40 & 24.94 & 24.65 & 21.40 & 18.85 & 23.23 \\
\hline An & 21.81 & 20.85 & 18.23 & 20.43 & 26.75 & 26.96 & 27.48 & 30.46 & 28.68 \\
\hline $\mathrm{Ne}$ & 1.99 & 3.85 & 4.04 & 0.77 & 0.00 & 0.00 & 0.00 & 0.00 & 0.00 \\
\hline Wo & 9.45 & 14.64 & 12.12 & 13.83 & 8.42 & 8.71 & 13.83 & 10.96 & 11.03 \\
\hline En & 5.78 & 9.04 & 8.14 & 8.34 & 10.40 & 12.55 & 12.02 & 11.65 & 9.76 \\
\hline $\mathrm{Fa}$ & 3.13 & 4.74 & 3.07 & 4.75 & 7.12 & 8.73 & 9.03 & 7.19 & 5.22 \\
\hline Fo & 11.16 & 8.71 & 8.17 & 6.35 & 5.28 & 3.38 & 2.23 & 4.06 & 4.08 \\
\hline Fs & 6.65 & 5.04 & 3.39 & 3.96 & 3.99 & 2.59 & 1.85 & 2.76 & 2.41 \\
\hline $\mathrm{Mt}$ & 4.57 & 4.63 & 6.39 & 4.68 & 4.25 & 4.33 & 4.26 & 4.93 & 3.05 \\
\hline Il & 3.14 & 3.20 & 5.51 & 3.27 & 2.67 & 2.81 & 2.73 & 3.58 & 3.77 \\
\hline Ap & 0.90 & 1.22 & 0.67 & 0.55 & 1.26 & 0.47 & 0.55 & 0.33 & 0.71 \\
\hline
\end{tabular}

C- Trace Elements in ppm

\begin{tabular}{|c|c|c|c|c|c|c|c|c|c|}
\hline $\mathrm{Sr}$ & 3.75 & 435.00 & 550.00 & 335.00 & 365.00 & 345.00 & 355.00 & 370.00 & 425.00 \\
\hline$\overline{\mathrm{Zn}}$ & 95.00 & 245.00 & 90.00 & 601.00 & 80.00 & 80.00 & 145.00 & 80.00 & 70.00 \\
\hline $\mathrm{Ni}$ & 160.00 & 164.00 & 143.00 & 108.00 & 115.00 & 106.00 & 106.00 & 106.00 & 73.00 \\
\hline $\mathrm{Cr}$ & 131.00 & 154.00 & 130.00 & 120.00 & 124.00 & 109.00 & 125.00 & 129.00 & 106.00 \\
\hline $\mathrm{Li}$ & 3.00 & 10.00 & 5.00 & 10.00 & 5.00 & 5.00 & 10.00 & 10.00 & 10.00 \\
\hline $\mathrm{Pb}$ & - & 95.00 & 100.00 & 55.00 & 15.00 & 75.00 & 63.00 & 80.00 & 55.00 \\
\hline $\mathrm{Cd}$ & 10.00 & 20.00 & 15.00 & 10.00 & 15.00 & 15.00 & 10.00 & 10.00 & 10.00 \\
\hline $\mathrm{Ba}$ & 140.00 & 125.00 & 195.00 & 310.00 & 75.00 & 80.00 & 325.00 & 140.00 & 265.00 \\
\hline $\mathrm{Rb}$ & 8.00 & 10.00 & 12.00 & 14.00 & 9.00 & 11.00 & 15.00 & 10.00 & 12.00 \\
\hline $\mathrm{Nb}$ & 22.00 & 26.00 & 19.00 & 40.00 & 20.00 & 24.00 & 26.00 & 10.00 & 13.00 \\
\hline $\mathrm{Y}$ & 16.00 & 22.00 & 18.00 & 26.00 & 15.00 & 19.00 & 16.00 & 15.00 & 11.00 \\
\hline $\mathrm{C}$ & 45.00 & 70.00 & 66.00 & 55.00 & 46.00 & 61.00 & 66.00 & 47.00 & 25.00 \\
\hline$\underline{\mathrm{Se}}$ & 26.00 & 22.00 & 25.00 & 30.00 & 33.00 & 20.00 & 25.00 & 22.00 & 26.00 \\
\hline
\end{tabular}

Table 2: Microprobe analysis of olivines in xenoliths

\begin{tabular}{|c|c|c|c|c|c|c|c|}
\hline Sample & NE1 & NE2 & NE3 & NE4 & NE5 & NE6 & NE7 \\
\hline \multicolumn{8}{|c|}{ NO. wt $\%$} \\
\hline $\mathrm{Si02}$ & 41.94 & 41.48 & 40.22 & 41.67 & 41.09 & 42.30 & 42.30 \\
\hline Ti02 & 0.06 & 0.00 & 0.00 & 0.02 & 0.00 & 0.03 & 0.02 \\
\hline AI203 & 0.00 & 0.00 & 0.00 & 0.04 & 0.02 & 0.08 & 0.00 \\
\hline $\mathrm{FeO} *$ & 8.70 & 8.30 & 8.68 & 8.60 & 8.70 & 8.25 & 8.27 \\
\hline $\mathrm{MnO}$ & 0.09 & 0.13 & 0.10 & 0.12 & 0.11 & 0.09 & 0.06 \\
\hline $\mathrm{MqO}$ & 50.42 & 51.40 & 49.69 & 51.28 & 50.60 & 50.38 & 49.60 \\
\hline $\mathrm{CaO}$ & 0.02 & 0.00 & 0.00 & 0.00 & 0.09 & 0.06 & 0.01 \\
\hline $\mathrm{Na} 20$ & 0.00 & 0.00 & 0.02 & 0.02 & 0.00 & 0.00 & 0.00 \\
\hline K20 & 0.00 & 0.00 & 0.00 & 0.00 & 0.00 & 0.00 & 0.00 \\
\hline $\mathrm{Cr} 203$ & 0.07 & 0.05 & 0.02 & 0.01 & 0.03 & 0.01 & 0.05 \\
\hline Total & 101.30 & 101.36 & 98.73 & 101.76 & 100.64 & 101.20 & 100.31 \\
\hline
\end{tabular}


Am. J. Applied Sci., 4 (7): 491-495, 2007

Table 3: Microprobe analysis of orthopyroxene in xenoliths

\begin{tabular}{|c|c|c|c|c|c|c|c|}
\hline$\underline{\text { Sample }}$ & NE1 & NE2 & NE3 & NE4 & NE5 & NE6 & NE7 \\
\hline \multicolumn{8}{|l|}{ NO. wt $\%$} \\
\hline $\mathrm{Si02}$ & 55.02 & 56.70 & 56.49 & 56.60 & 56.35 & 56.11 & 56.75 \\
\hline Ti02 & 0.15 & 0.07 & 0.03 & 0.04 & 0.06 & 0.05 & 0.00 \\
\hline AI203 & 1.85 & 2.58 & 2.35 & 2.58 & 2.46 & 2.18 & 2.16 \\
\hline $\mathrm{FeO}^{*}$ & 5.37 & 5.64 & 5.86 & 5.85 & 6.07 & 5.85 & 5.69 \\
\hline $\mathrm{MnO}$ & 0.09 & 0.09 & 0.11 & 0.12 & 0.11 & 0.09 & 0.11 \\
\hline $\mathrm{MgO}$ & 35.15 & 34.18 & 34.59 & 33.99 & 34.95 & 34.86 & 33.98 \\
\hline $\mathrm{Na} 20$ & 0.05 & 0.03 & 0.08 & 0.04 & 0.08 & 0.06 & 0.08 \\
\hline Cr203 & 0.57 & 0.40 & 0.42 & 0.41 & 0.30 & 0.42 & 0.45 \\
\hline K20 & 0.00 & 0.00 & 0.00 & 0.00 & 0.00 & 0.00 & 0.00 \\
\hline $\mathrm{CaO}$ & 0.44 & 0.50 & 0.45 & 0.44 & 0.48 & 0.45 & 0.44 \\
\hline Total & 98.69 & 100.19 & 100.38 & 100.07 & 100.86 & 100.07 & 99.66 \\
\hline Sample & NE1 & NE2 & NE3 & NE4 & NE5 & NE6 & NE7 \\
\hline \multicolumn{8}{|l|}{ NO. $w t \%$} \\
\hline $\mathrm{Si02}$ & 53.85 & 53.16 & 53.30 & 53.15 & 53.69 & 52.95 & 54.66 \\
\hline Ti02 & 0.28 & 0.29 & 0.23 & 0.23 & 0.25 & 0.21 & 0.03 \\
\hline AI203 & 2.82 & 2.85 & 6.67 & 3.66 & 3.50 & 3.62 & 3.85 \\
\hline $\mathrm{FeO}^{*}$ & 2.15 & 2.07 & 2.28 & 2.55 & 2.58 & 2.49 & 2.20 \\
\hline $\mathrm{MnO}$ & 0.07 & 0.05 & 0.08 & 0.08 & 0.07 & 0.05 & 0.04 \\
\hline $\mathrm{MqO}$ & 16.62 & 17.38 & 17.62 & 17.06 & 16.36 & 16.53 & 17.45 \\
\hline $\mathrm{CaO}$ & 21.08 & 21.15 & 21.24 & 21.81 & 21.66 & 21.70 & 19.65 \\
\hline $\mathrm{Na} 20$ & 1.04 & 1.14 & 1.04 & 1.32 & 1.73 & 1.37 & 1.82 \\
\hline K20 & 0.00 & 0.01 & 0.00 & 0.00 & 0.07 & 0.00 & 0.00 \\
\hline Cr203 & 1.38 & 1.18 & 1.35 & 0.81 & 0.99 & 1.02 & 1.42 \\
\hline Total & 99.29 & 99.28 & 103.81 & 100.67 & 100.90 & 99.94 & 101.12 \\
\hline Table 4: & lysis of & roxene 1 & & & & & \\
\hline Sample & NE1 & NE2 & NE3 & NE4 & NE5 & NE6 & NE7 \\
\hline \multicolumn{8}{|l|}{ NO. wt $\%$} \\
\hline $\mathrm{Si02}$ & 53.85 & 53.16 & 53.30 & 53.15 & 53.69 & 52.95 & 54.66 \\
\hline Ti02 & 0.28 & 0.29 & 0.23 & 0.23 & 0.25 & 0.21 & 0.03 \\
\hline AI203 & 2.82 & 2.85 & 6.67 & 3.66 & 3.50 & 3.62 & 3.85 \\
\hline $\mathrm{FeO}^{*}$ & 2.15 & 2.07 & 2.28 & 2.55 & 2.58 & 2.49 & 2.20 \\
\hline $\mathrm{MnO}$ & 0.07 & 0.05 & 0.08 & 0.08 & 0.07 & 0.05 & 0.04 \\
\hline $\mathrm{MqO}$ & 16.62 & 17.38 & 17.62 & 17.06 & 16.36 & 16.53 & 17.45 \\
\hline $\mathrm{CaO}$ & 21.08 & 21.15 & 21.24 & 21.81 & 21.66 & 21.70 & 19.65 \\
\hline $\mathrm{Na} 20$ & 1.04 & 1.14 & 1.04 & 1.32 & 1.73 & 1.37 & 1.82 \\
\hline K20 & 0.00 & 0.01 & 0.00 & 0.00 & 0.07 & 0.00 & 0.00 \\
\hline $\mathrm{Cr} 203$ & 1.38 & 1.18 & 1.35 & 0.81 & 0.99 & 1.02 & 1.42 \\
\hline Total & 99.29 & 99.28 & 103.81 & 100.67 & 100.90 & 99.94 & 101.12 \\
\hline
\end{tabular}

Table 5: Microprobe analysis of spinals in xenoliths

\begin{tabular}{|c|c|c|c|c|c|c|c|}
\hline Sample & NE1 & NE2 & NE3 & NE4 & NE5 & NE6 & NE7 \\
\hline \multicolumn{8}{|l|}{ NO. $w t \%$} \\
\hline $\mathrm{Si} 02$ & 0.09 & 0.02 & 0.03 & 0.10 & 0.04 & 0.11 & 0.04 \\
\hline Ti02 & 0.16 & 0.17 & 0.10 & 0.21 & 0.17 & 0.14 & 0.17 \\
\hline AI203 & 52.05 & 50.99 & 48.87 & 51.26 & 49.01 & 51.94 & 50.74 \\
\hline $\mathrm{FeO} *$ & 11.65 & 12.74 & 15.09 & 11.19 & 12.92 & 15.85 & 16.19 \\
\hline $\mathrm{MnO}$ & 0.14 & 0.17 & 0.12 & 0.11 & 0.14 & 0.11 & 0.13 \\
\hline $\mathrm{MgO}$ & 20.69 & 19.66 & 18.96 & 20.12 & 20.18 & 17.85 & 17.88 \\
\hline $\mathrm{CaO}$ & 0.00 & 0.00 & 0.00 & 0.00 & 0.00 & 0.00 & 0.00 \\
\hline Cr203 & 15.54 & 16.20 & 15.95 & 15.92 & 16.90 & 14.69 & 14.59 \\
\hline Total & 100.32 & 99.95 & 99.12 & 98.91 & 99.36 & 100.69 & 99.74 \\
\hline
\end{tabular}

\section{RESULTS AND DISCUSSION}

The north-eastern basalts are unsaturated with respect to silica content. These rocks are classified as alkali olivine basalt. The low quantity of trace elements $(\mathrm{Rb}, \mathrm{Li})$ gives evidence that the magma was not stored in the crust long enough to assimilate or equilibrate with crust material. The primary alkali basalt can be formed by an extremely small degree of melting at pressure as low as $13 \mathrm{kbar}$ and can fractionate to holistic liquids between 4 and $12 \mathrm{Kbar}$ pressure. The alkali basalt melts can be derived in the low velocity zone at 
an approximate depth of $85-95 \mathrm{Km}$ (30 kbar) by about $5 \%$ partial melting and by about $10 \%$ in the lithosphere at $60-90 \mathrm{Km}$ (19-27 kbar). In general, alkali basalts are widespread in continental plate interiors and are usually associated with continental rifting ${ }^{[14]}$.

They represent relatively small degrees of partial melting of deep mantle sources and are the main source of mantle xenoliths ${ }^{[5,15]}$, while the presence of xenoliths suggests fast ascent from great depth ${ }^{[16]}$. Based on the prevention information, Rooney, et al. ${ }^{[17]}$ reported the recent basalt of Ethiopian rift were produced as small degree of partial melting predictive at 15-25 Kbar. The temperature estimation from the equilibrium involving $\mathrm{Fe} / \mathrm{Mg}$ in orthopyroxene and clinopyroxene $\left.{ }^{[6,14}, 18,19\right]$ could reflect mantle conditions. Temprature estimates give the average of $970-1090 \mathrm{C}^{\circ}$ for ultramafic xenoliths $^{[19]}$ such tempratures are good enough to cause partial melting of ultramafic rocks to form alkali olivine basalt $^{[20]}$. The maximum pressure can be estimated by the absence of garnet and stability of spinal in the xenoliths $^{[14]}$. The stability of spinal relative to garnet depends on its $\mathrm{Cr}$-content ${ }^{[21]}$. The $\mathrm{Cr}$ concentration in the investigated spinal range between 14.59 to 16.90 $\mathrm{Wt} \% \mathrm{Cr}_{2} \mathrm{O}_{3}$. This relatively low $\mathrm{Cr}$-content raises the stability of spinal up to a pressure of about $20 \mathrm{Kbar}$. These rocks are equilibrated at a depth greater than 65 $\mathrm{Km}$. The mineral assemblages, chemistry and textures indicate derivation and equilibration under upprmantle conditions.

\section{ACKNOWLEDGMENTS}

This study was prepared during a sabbatical leave offered to the senior author from Jordan University.

\section{REFERENCES}

1. Fediuk, F. and H. Al-Fugha, 1999. Dead Sea Region Fault-controlled chemistry of Cenozoic Volcanics. Geolines ( Praha), 9: 29-34.

2. Bender, F., 1968. Geologies van Jordanian, Borntraeger, Berlin and Stuttgart, pp: 230.

3. Barberi, F., P. Capaldi, G. Gasperihi, G. Marinelli, Santaroce, M. Treuil and J. Varet, 1979. Recent Basaltic volcanism of Jordan and its implication on the geodynamic history of the Dead Sea Shear Zone, in ternat. Symp. Geodynamic Evol. of the Afra-Arabian Rift system, Rome, Italy.

4. Ghent, E., R. Coleman and D. Hadly, 1980. Ultramafic inclusion and host alkali olivine basalt of the southern coastal plain of the Red Sea, SaudiArabic. Am. J. Sci., 280a: 499-527.

5. Bergman, S.C., 1987. Historical review in: Nixon, P. H., ed. Mantle xenoliths. A. Wiley-inter-science, NewYork, pp: 5-9.
6. Mc Guire, A., 1988. The mantle beneath the Dead Sea margin, xenoliths from western Saudi-Arabia. Tectophysics, 150: 101-119.

7. El-Sharkawi, M.A., 1982. Iherzolite xenoliths in shihan V.G basalt central Jordan. J. Uni. Kuwait, pp: 287-301.

8. Nasir, S. and H.Al Fugha, 1988. Spinal Iherzolite xenoliths from the aritain volcano. NE Jordan. Miner. Petrol., 39: 127-137.

9. AL- H.Fugha, 1996. Basinets with mantle xenoliths from jabal El-Dabusa in west central Jordan. J. Muthah, 11: 35-53.

10. Person, D.G., D.C. Canil and S. Shiry, 2003. Mantle samples included in volcanic rocks: xenoliths and Diamond, in: Carlson P.W (Ed): treaties on Geochemistry-volume 2, The mantle.

11. Mercier, J. and A. Nicoles, 1975. Textures and fabric of upper-mantle periodtites as illustrated by xenoliths from basalts. J. Petrol, 16: 454-487.

12. Wedpohl, K.H., 1975. Origin of the tertiary basaltic in the northern Hessian depression. Contrib. Mineral. Petrol., 89: 122-143.

13. Nasir, S. and A. Safarjalani, 2000. Lithospheric petrology beneath the northern part of the Arabian Plate in Syria: evidence from xenoliths in the alkali basalt. J. African Earth Sci., 1: 149-168.

14. Wilson, M., 1989. Igneous petrogenesis, a global tectonic approach. Unwin, Hyman 2td, London, pp: 466.

15. Carswell, D. and F. Gibbs, 1987. Evolution of mineral thermometer and barometer applicable to garnet Iherzolite assemblage contrib. Mineral. Petrol., 95: 499-511.

16. Spera, F.J., 1984. Carbon dioxide in petrogenesis 3: Role of volatiles in the ascent of alkaline magma with special reference to xenoliths-bearing mafic lava Contrib. Mineral. Petrol., 88: 217-232.

17. Rooney, T., T. Furman, G. Yigu and D. Ayalew, 2005. Structure of the Ethiopian lithosphere: Xenoliths evidence in the main Ethiopian Rift. Geochemical et Cosmochica Acta, 69: 3889-3910.

18. Gutmann, J.T., 1986. Origin of four and five phase ultramafic xenoliths from Sonora Mexico. Am. Mineral, 71: 1076-1084.

19 Wells, P.R, 1977. Pyroxene thermometry in simple and complex systems contrib. Mineral Petrol., 62: 129-139.

20. Ring Wood, A.E., 1973. Phasetrans formations and their bearing on the dynamics and their bearing on the dynamics on the mantle fort. Schr. Min., 50: 113-139.

21. Neill, O., 1981. The transition between spinal Iherzolite and garnet Iherzolite. Contrib. Mineral petrol, 77: 185-194. 